\title{
ANALISIS KUAT TEKAN BETON FAST TRACK DENGAN BAHAN TAMBAH MASTER GLENIUM ACE 8111
}

\section{COMPRESSION STRENGTH ANALYSIS OF CONCRETE $F A S T$ TRACK WITH MASTER GLENIUM ACE 8111 ADDITIVES}

\author{
Damasya Haptakirana Sukmaningtyas', Amris Azizi², M Agus Salim \\ Program Studi S1 Teknik Sipil, Fakultas Teknik dan Sains \\ Universitas Muhammadiyah Purwokerto
}

\section{Informasi Artikel \\ Dikirim, \\ Direvisi, \\ Diterima,}

\section{Korespondensi Penulis:}

Damasya Haptakirana Sukmaningtyas

Program Studi Teknik Sipil Universitas Muhammadiyah Purwokerto

JL. K.H. Ahmad Dahlan

Purwokerto, 53182

Email: damasya@gmail.com

\begin{abstract}
ABSTRAK
Berbagai penelitian dan percobaan dibidang beton dilakukan sebagai upaya untuk meningkatkan kualitas beton, teknologi bahan dan teknik-teknik pelaksanaan yang diperoleh dari hasil penelitian dan percobaan tersebut dimaksudkan untuk menjawab tuntutan yang semakin tinggi terhadap pemakaian beton serta mengatasi kendala-kendala yang sering terjadi pada pelaksanaan pekerjaan di lapangan. Salah satu cara untuk meningkatkan kekuatan beton adalah meningkatkan pemadatannya, yaitu meminimumkan pori atau rongga yang terbentuk di dalam beton. Penggunaan bahan tambah (admixture) dapat membantu memecahkan permasalahan tersebut. Tujuan dari penelitian ini adalah mengetahui kuat tekan beton dengan variasi penambahan Master Glenium Ace 8111 dan mengetahui jumlah optimum bahan tambah Master Glenium 8111 agar mencapai kuat tekan maksimum beton pada umur 7 hari. Komposisi campuran superplasticizer yang digunakan dalam penelitian ini adalah $0 \%, 0.1 \%, 0.2 \%, 0.3 \%$ dari berat semen untuk semua variasi Benda uji yang digunakan adalah berbentuk silinder, mutu beton yang direncanakan $45 \mathrm{MPa}$ yang diuji pada umur 28 hari dengan terlebih dahulu dilakukan perawatan sebelum pengujian. Penelitian ini menguji beton dengan benda uji selinder untuk uji tekan ( diameter $150 \mathrm{~mm}$ dan tinggi $300 \mathrm{~mm}$ ) sebanyak 36 sampel dan terdiri dari 4 variasi dan masing-masing variasi sebanyak 3 sampel. Dari penelitian diperoleh bahwa kuat tekan beton yang tertinggi terdapat pada campuran beton zat additive 0,3\% yaitu sebesar 29,09 MPa dan kuat tekan beton yang terendah terdapat pada campuran beton $0 \%$ yaitu sebesar $20,13 \mathrm{MPa}$. Bahwa penambahan zat additive mempunyai kuat tekan lebih tinggi dibandingkan dengan beton variasi campuran zat additive lainnya. Adukan dengan tingkat kelecakan tinggi mempunyai resiko yang besar terhadap terjadinya bleeding, hal ini terjadi pada semua sampel beton.
\end{abstract}

Kata Kunci : Beton, Master Glenium Ace 8111

\section{ABSTRACT}

Various studies and experiments in education of concrete are carried out in an effort to improve the quality of concrete, technology and every technique that obtained from experiment and research its intended to answer the high-demands against the use of concrete and overcoming the obstacles that often occur in the implementation of work in the field and there is a way to increase the strength of concrete is increase the compaction, which is minimizing the pores or cavities that form in the concrete. Using of added naterials (admixture) can help solving the problem ehe. The purpose of this study is to determine the compressive strength of concrete with variations Master Glenium Ace 8111 in addition and know how much optinum amount of master glenium added ingredients 8111 in order to achieve maximum compressive strength concrete at the age of 7 days. Mix composition superplasticizer used in this experiment are $0 \%, 0.1 \%, 0.2 \%$, $0.3 \%$ the weight cement for all variations the specimen used is a cylindrical shape, planned concrete quality $45 \mathrm{MPa}$ which was tested at the age of 28 days with treat before it be tested. this experiment tested the concrete with a cylindrical specimen for the compression test ( diameter $150 \mathrm{~mm}$ and height $300 \mathrm{~mm}$ ) as many 36 samples and consist of 4 variations and each variation of 3 samples. From the research, it was found that the high compressive strength of concrete was found in the concrete mixture $0,3 \%$ additives, which $29,09 \mathrm{MPa}$ and lowest concrete compressive strength found in the concrete mixture $0 \%$ which $20,13 \mathrm{MPa}$. That addition additives have high compressive strength 
than the mixed variation concrete other additives. If mixtures with high levels of discomfort have high risk of bleeding, and this happened for all concrete samples

Keyword : Concrete, Master Glenium Ace 8111

\section{PENDAHULUAN}

Perkembangan teknologi pada era serkarang sangat pesat. Salah satunya teknologi di bidang konstruksi bangunan, seperti beton. Hampir pada setiap aspek kehidupan dijumpai baik secara langsung maupun tidak langsung, sebagai contoh adalah jalan dan jembatan yang strukturnya terbuat dari beton, bangunan bertingkat, plat lantai, lapangan terbang, pemecah gelombang, dan bendungan. Adanya tuntutan waktu terhadap progress pelaksanaan proyek, perbaikan jalan yang diutamakan, penggantian persimpangan yang sibuk atau padat seringkali memaksa agar beton dapat menunjukan performance yang optimal di waktu yang lebih cepat dari waktu yang dibutuhkan beton normal yang memadahi untuk menahan beban lalu lintas. Konstruksi jalur cepat memerlukan kekuatan usia dini yang tinggi. Salah satu faktor yang harus diperhatikan dalam mempengaruhi sifat-sifat ini adalah komposisi campuran beton. Pemberian bahan tambah bertujuan untuk mengubah satu atau lebih dari sifat beton sewaktu dalam keadaan segar ataupun setelah mengeras, misalnya untuk mempercepat pengerasan, meningkatkan workability, menambah kuat tekan, menambah daktilitas (mengurangi sifat getas), serta mengurangi keretakan saat pengerasan.

Akibat adanya faktor permasalahan yang ada, diperlukan suatu bahan tambah yang dapat membantu proses tersebut. Master Glenium Ace 8111 merupakan bahan tambah yang dapat membantu beton meningkatkan perfomancenya pada waktu yang lebih cepat. Master Glenium Ace 8111 adalah bahan tambah generasi baru campuran air pereduksi tinggi, berdasarkan rantai teknologi eter polycarboxlylate yang dimodifikasi. Master Glenium ACE 8111 bebas klorida, memenuhi persyaratan ASTM (American Standard Testing and Material) C 494 untuk Tipe A dan Tipe F dan Master Glenium 8111 juga kompatibel dengan semua semen yang memenuhi standar ASTM (American Standard Testing and Material). Master Glenium 8111 berfungsi mengurangi kadar air seperti melamin dan sulfonate naftalena didasarkan pada polimer yang diserap oleh butiran semen. Master Glenium 8111 membungkus area permukaan butiran di bagian paling tahap awal dari proses pencampuran beton. Master Glenium 8111 juga memiliki kemampuan kerja tinggi, kohesi superior, kekuatan awal yang tinggi dan modulus elastisitas yang tinggi.

\section{METODE PENELITIAN}

\subsection{Lokasi dan Waktu Penelitian}

Rangkaian kegiatan penelitian dilaksanakan di Laboratorium PT. Panca Karya Sentosa Bulupayung, Cilacap, penelitian dilakukan pada tanggal 1 Juli - 15 Juli 2020.

\subsection{Jenis Penelitian}

Penelitian ini menggunakan metode eksperimen atau percobaan yang dilakukan di laboratorium untuk mengetahui hubungan yang terjadi dari variabel sebagai hasil percobaan. Penelitian ini menggunakan beberapa sampel dengan komposisi Master Glenium Ace 8111 yang berbeda. Peneliti bertujuan untuk mengetahui berapa besar kuat tekan yang dihasilkan dan mencari kuat tekan optimum dari sampel tersebut dengan menggunakan job mix mutu beton FS-45 ( $\mathrm{K}-400)$. Variabel bebas dalam penelitian ini adalah penambahan zat additive Master Glenium Ace 8111. Sedangkan untuk variabel terikat pada penelitian ini adalah kuat tekan beton. Untuk mengendalikan kedua variabel tersebut, diperlukan variabel yang dibuat konstan sehingga pengaruh variabel bebas terhadap variabel terikat tidak dipengaruhi oleh faktor luar yang tidak diteliti.

\subsection{Material dan Alat}

\subsubsection{Bahan}

Untuk melakukan penelitian ini yang harus di persiapakan sebelum memulai penelitian adalah mempersiapkan bahan-bahan atau material yang diperlukan, yaitu sebagai berikut:

1. Semen

Dalam penelitian ini semen yang digunakan adalah semen Portland tipe I merk semen Gresik kemasan $50 \mathrm{~kg}$ yang banyak tersedia di pasaran.

2. Agregat Halus

Agregat halus yang digunakan dalam penelitian ini berasal dari eks Cikalong yang dibeli dari tempat penjualan pasir.

3. Agregat Kasar

Agregat kasar yang digunakan dalam penelitian ini dibeli dari tempat crushing batu yang berlokasi di Bulupayung Kab.Cilacap.

4. Air

Air yang digunakan dalam penelitian ini berasal dari air yang tersedia di Laboratorium PT. Panca Karya Sentosa Bulupayung, Cilacap 
5. Master Glenium Ace 8111

Master Glenium Ace 8111 yang digunakan dapat banyak tersedia di pasaran.

\subsubsection{Alat}

a. Alat untuk pembuatan benda uji

1) Skop ( sebagai alat untuk memindahkan campuran )

2) Plat besi ( sebagai alas untuk uji slump )

3) Cetakan ( sebagai wadah cetakan benda uji )

4) Alat uji slump

5) Alat ukur ( untuk mengukur benda uji )

6) Concrete Mixer ( untuk mencampurkan bahan-bahan )

b. Alat untuk menguji agregat halus dan kasar.
1) Saringan
2) Timbangan
4) Erlenmeyer
3) Oven
5) Cawan
6) Mesin siever shaker

\subsection{Proses Penelitian}

\subsubsection{Cara Pengumpulan Data}

Hal yang terpenting dalam menyelesaikan penelitian pengaruh penambahan Master Glenium Ace 8111 sebagai bahan tambah terhadap kuat tekan beton adalah pengumpulan data untuk mendukung data-data yang disusun. Data didapat melalui eksperimen yang dilakukan dengan percobaan dan pengujian benda uji di Laboratorium. Pengujian tersebut meliputi uji kuat tekan beton silinder. Data-data disajikan dengan tampilan grafik dan tabel.

\section{HASIL DAN PEMBAHASAN}

\subsection{Pengujian Material}

Setelah melakukan pengujian, diperoleh data-data pengujian agregat halus, pengujian agregat kasar, hasil slump test dan pengujian sifat mekanik beton.

\subsubsection{Pemeriksaan Agregat Halus}

Pemeriksaan agregat halus berupa pengujian gradasi, pengujian berat jenis dan pengujian kadar lumpur.

1. Pemeriksaan gradasi pasir

Hasil pengujian gradasi untuk agregat halus masuk dalam zona 2. Metode pengujian ini berdasarkan SNI 031968-1990 tentang metode pengujian analisis saringan agregat halus dan kasar. Hasil pemeriksaan dapat dilihat dalam Gambar 1.

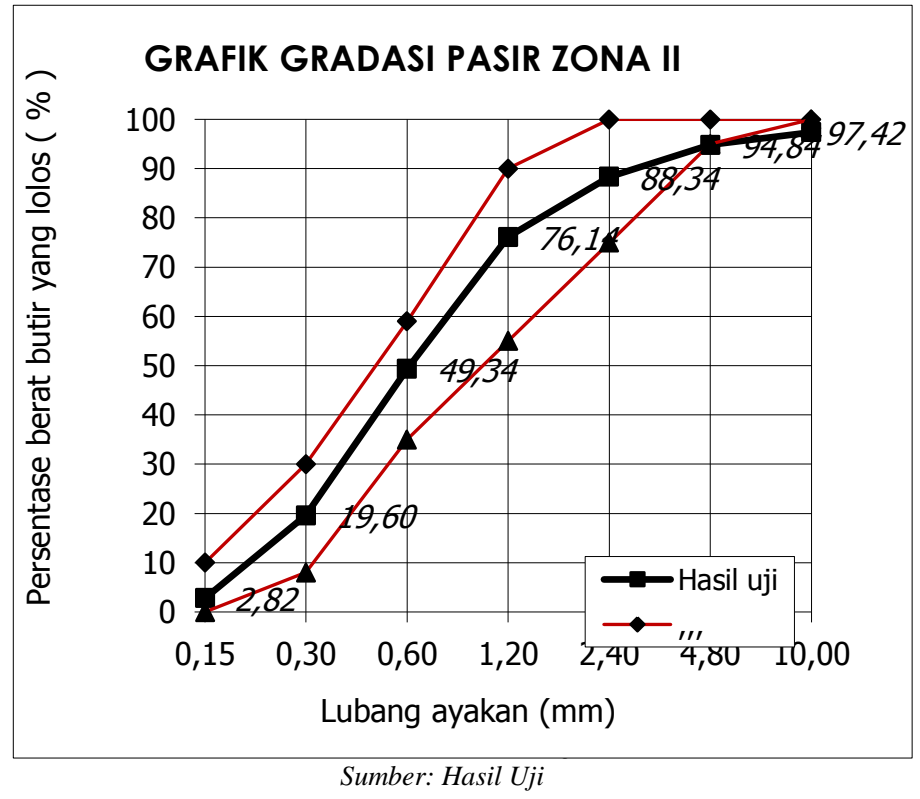


2. Pemeriksaan berat jenis pasir

Dari hasil pengujian berat jenis pasir Cikalong tersebut didapat berat jenis sebesar 2,78.

3. Pemeriksaan kadar lumpur pasir

Dari pemeriksaan kadar lumpur pasir didapat nilai rata-rata kadar lumpur pasir Cikalong yaitu $0,83 \%$, memenuhi syarat kandungan lumpur maksimum pada pasir yaitu rata-rata 5\% yang ditetapkan menurut SNI 03-4428-1997 tentang pemeriksaan bahan bangunan pasir beton. Maka pasir dapat digunakan untuk material beton pada penelitian.

\subsection{Pemeriksaan Agregat Kasar}

Pemeriksaan agregat kasar meliputi pengujian berat jenis, pengujian gradasi, dan abrasi.

\subsubsection{Pengujian berat jenis}

Dari pengujian berat jenis masing-masing agregat diperoleh hasil 2,76 untuk agregat maksimum $40 \mathrm{~mm}$

\subsubsection{Pengujian gradasi agregat kasar}

Metode pengujian ini berdasarkan SNI 03-1968-1990 tentang metode pengujian analisis saringan agregat halus dan kasar. Hasil pengujian gradasi agregat kasar dapat dilihat pada gambar 2.

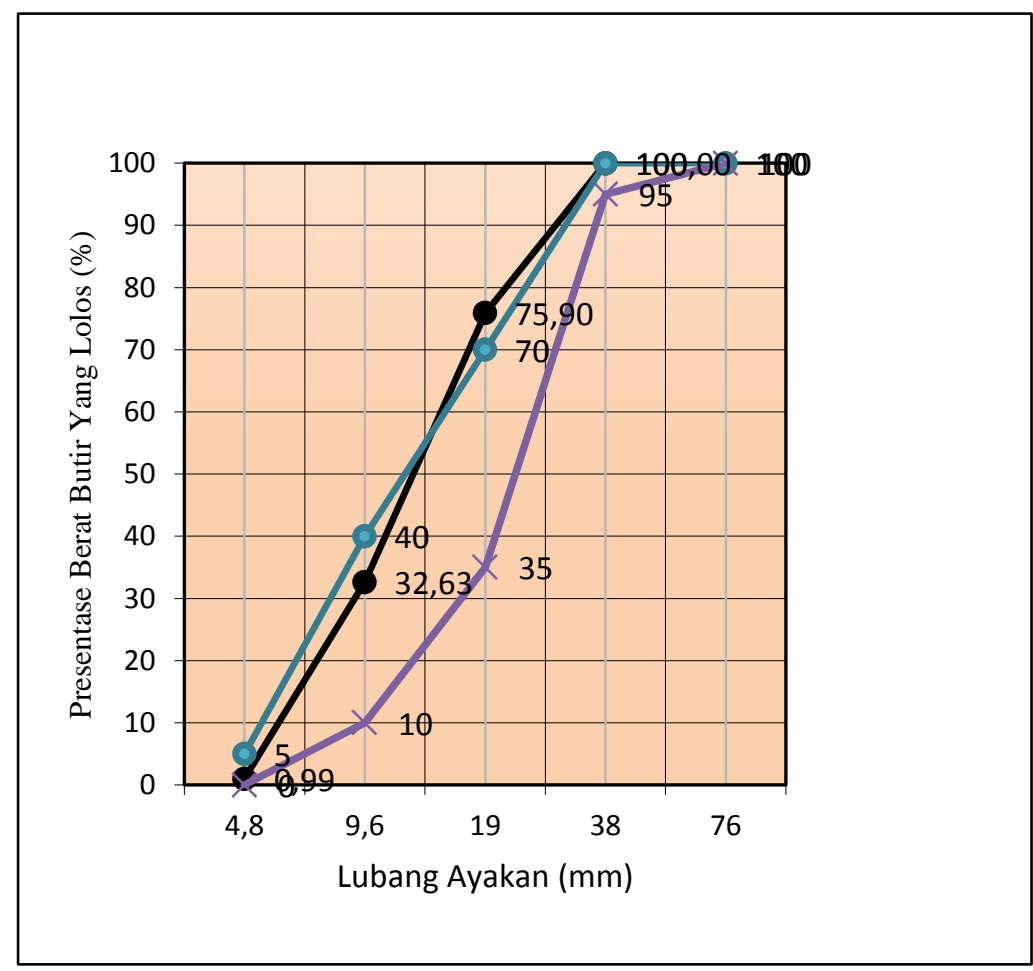

Gambar 2. Grafik Gradasi Agregat Kasar Maksimum $40 \mathrm{~mm}$ Sumber: Hasil Uji

\subsubsection{Pengujian abrasi}

Hasil pengujian agregat kasar dengan menggunakan mesin abrasi Los Angeles didapat nilai keausan agregat maksimum $40 \mathrm{~mm}$ sebesar 19,78\%, Sesuai dengan persyaratan SNI 03-2417-1990 (Metode Pengujian keausan Agregat Dengan Mesin Abrasi Los Angeles) yaitu keausan maksimum 40\%. Sehingga agregat kasar tersebut dapat digunakan sebagai bahan pembuat beton.

\subsection{Pengujian Slump}

Pengujian slump dilakukan setiap kali membuat adukan untuk benda uji, dari hasil pengujian slump test di dapat rata-rata hasil seperti tabel 1 .

Tabel 1. Nilai slump adukan

\begin{tabular}{ccccccc}
\hline Tipe Beton & Adukan & $\begin{array}{c}\text { Nilai } \\
\text { Slump }\end{array}$ & $\begin{array}{c}\text { Tipe } \\
\text { Sampel }\end{array}$ & Jumlah & Agregat & Rata-rata \\
\hline Beton Normal & Adukan 1 & $3 \mathrm{~cm}$ & & 3 Buah & Uk. $40 \mathrm{~mm}$ & $3,33 \mathrm{~cm}$ \\
\hline
\end{tabular}




\begin{tabular}{|c|c|c|c|c|c|c|}
\hline \multirow{5}{*}{ Beton Additive $0,1 \%$} & Adukan 2 & $4 \mathrm{~cm}$ & Silinder & 3 Buah & Uk. $40 \mathrm{~mm}$ & \\
\hline & Adukan 3 & $3 \mathrm{~cm}$ & & 3 Buah & Uk. $40 \mathrm{~mm}$ & \\
\hline & Adukan 1 & $5,5 \mathrm{~cm}$ & & 3 Buah & Uk. $40 \mathrm{~mm}$ & \\
\hline & Adukan 2 & $5,5 \mathrm{~cm}$ & Silinder & 3 Buah & Uk. $40 \mathrm{~mm}$ & $5,3 \mathrm{~cm}$ \\
\hline & Adukan 3 & $5 \mathrm{~cm}$ & & 3 Buah & Uk. $40 \mathrm{~mm}$ & \\
\hline \multirow{2}{*}{ Beton Additive 0,2\% } & Adukan 1 & $7 \mathrm{~cm}$ & & 3 Buah & Uk. $40 \mathrm{~mm}$ & \\
\hline & Adukan 2 & $6,5 \mathrm{~cm}$ & Silinder & 3 Buah & Uk. $40 \mathrm{~mm}$ & $6,66 \mathrm{~cm}$ \\
\hline \multirow{4}{*}{ Beton Additive $0,3 \%$} & Adukan 3 & $6,5 \mathrm{~cm}$ & & 3 Buah & Uk. $40 \mathrm{~mm}$ & \\
\hline & Adukan 1 & $8,5 \mathrm{~cm}$ & & 3 Buah & Uk. $40 \mathrm{~mm}$ & \\
\hline & Adukan 2 & $9,5 \mathrm{~cm}$ & Silinder & 3 Buah & Uk. $40 \mathrm{~mm}$ & $9 \mathrm{~cm}$ \\
\hline & Adukan 3 & $9 \mathrm{~cm}$ & & 3 Buah & Uk. $40 \mathrm{~mm}$ & \\
\hline
\end{tabular}

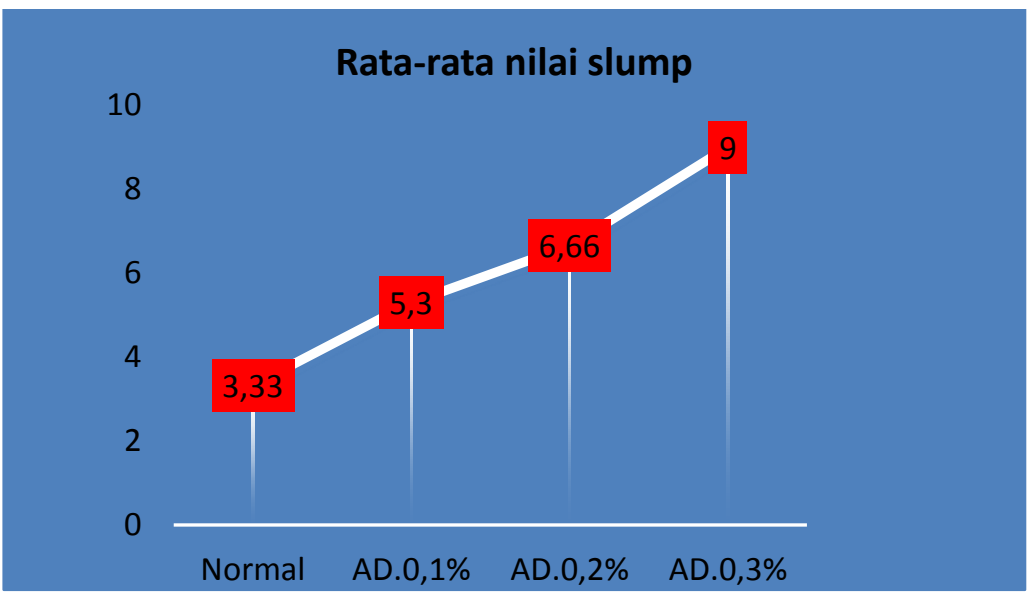

Gambar 3. Grafik Rata-rata Nilai Slump Sumber: Hasil Uji

\subsection{Hasil Pengujian Sifat Mekanik Beton}

Setelah dilakukan pembuatan dan perawatan benda uji, selanjutnya dilakukan pengujian kuat tekan benda uji tersebut. Pengujian kuat tekan beton pada penelitian ini dilakukan pada benda uji umur 1, 3, 7 hari dengan kuat tekan yang diharapkan bila berumur 28 hari direncanakan ( $\mathrm{f}^{\prime} \mathrm{c}$ ) sebesar $45 \mathrm{MPa}$ sebanyak 36 sampel dengan menggunakan metode SNI 03-1974-2011, yang terdiri dari empat variasi penambahan zat additive. Untuk masing-masing variasi dibuat 3 sampel untuk kuat tekan setiap variasi dengan pemberian zat additive (Master Glenium Ace 8111) sebesar $0 \%, 0.1 \%, 0.2 \%, 0,3 \%$ dari berat semen.

Kuat tekan beton dihitung dengan persamaan:

dimana:

$$
f \mathrm{c}^{\prime}=\frac{P}{A}
$$

$$
\begin{aligned}
& f \mathrm{c}^{\prime}=\text { kuat tekan beton }(\mathrm{MPa}) \\
& \mathrm{P}=\text { berat beban maksimum }(\mathrm{N}) \\
& \mathrm{A}=\text { luas permukaan benda uji }\left(\mathrm{mm}^{2}\right)
\end{aligned}
$$

Hasil perhitungan kuat tekan beton untuk varian umur selengkapnya disajikan dalam tabel 2. - 13. dan gambar 4. -7 .

Tabel 2. Hasil Uji Kuat Tekan Beton Normal Umur 1 Hari.

\begin{tabular}{ccccccccc}
\hline No & $\begin{array}{c}\text { Kode } \\
\text { Benda } \\
\text { Uji }\end{array}$ & Silinder & Berat & Umur & \multicolumn{2}{c}{ Beban Maksimal } & Fc' & $\begin{array}{c}\text { Rata-rata } \\
(\mathrm{MPa})\end{array}$ \\
\hline 1 & Normal & $15 \times 30$ & 13,02 & 1 & 191 & 19476.58 & 10,81 & \\
2 & Normal & $15 \times 30$ & 13,14 & 1 & 205 & 20904.18 & 11,60 & 10,96 \\
3 & Normal & $15 \times 30$ & 12,94 & 1 & 185 & 18864.75 & 10,47 & \\
\hline Sumber: Hasil Uji & & & & &
\end{tabular}


Tabel 3. Hasil Uji Kuat Tekan Beton Normal Umur 3 Hari.

\begin{tabular}{|c|c|c|c|c|c|c|c|c|}
\hline \multirow[t]{2}{*}{ No } & \multirow{2}{*}{$\begin{array}{c}\text { Kode } \\
\text { Benda } \\
\text { Uji }\end{array}$} & \multirow[t]{2}{*}{ Silinder } & \multirow{2}{*}{$\begin{array}{l}\text { Berat } \\
(\mathrm{Kg})\end{array}$} & \multirow{2}{*}{$\begin{array}{l}\text { Umur } \\
\text { (hari) }\end{array}$} & \multicolumn{2}{|c|}{ Beban Maksimal } & \multirow{2}{*}{$\begin{array}{c}\mathrm{Fc}^{\prime} \\
(\mathrm{MPa})\end{array}$} & \multirow{2}{*}{$\begin{array}{c}\text { Rata-rata } \\
\text { (MPa) }\end{array}$} \\
\hline & & & & & $(\mathrm{kN})$ & $(\mathrm{Kg})$ & & \\
\hline 1 & Normal & $15 \times 30$ & 13,26 & 3 & 328 & 33446.68 & 18,56 & \\
\hline 2 & Normal & $15 \times 30$ & 12,94 & 3 & 278 & 28348.1 & 15,73 & 18,2 \\
\hline 3 & Normal & $15 \times 30$ & 13,20 & 3 & 359 & 36607.8 & 20,32 & \\
\hline
\end{tabular}

Tabel 4. Hasil Uji Kuat Tekan Beton Normal Umur 7 Hari

\begin{tabular}{ccccccccc}
\hline No & $\begin{array}{c}\text { Kode Benda } \\
\text { Uji }\end{array}$ & Silinder & $\begin{array}{c}\text { Berat } \\
(\mathrm{Kg})\end{array}$ & $\begin{array}{c}\text { Umur } \\
(\text { hari })\end{array}$ & $\begin{array}{c}\text { Beban Maksimal } \\
(\mathrm{kN})\end{array}$ & $\begin{array}{c}\text { Fc' } \\
(\mathrm{Kg})\end{array}$ & $\begin{array}{c}\text { Rata-rata } \\
(\mathrm{MPa})\end{array}$ \\
\hline 1 & Normal & $15 \times 30$ & 12,84 & 7 & 323 & 32936.83 & 18,28 & 24,06 \\
2 & Normal & $15 \times 30$ & 13,26 & 7 & 425 & 43337.93 & 20,13 \\
3 & Normal & $15 \times 30$ & 13,24 & 7 & 319 & 32528.94 & 18,06 & \\
\hline \multicolumn{2}{l}{ Sumber: Hasil Uji } & & & & & &
\end{tabular}

Tabel 5. Hasil Uji Kuat Tekan Beton Additive 0,1\% Umur 1 Hari.

\begin{tabular}{ccccccccc}
\hline No & $\begin{array}{c}\text { Kode Benda } \\
\text { Uji }\end{array}$ & Silinder & Berat & Umur & $\begin{array}{c}\text { Beban Maksimal } \\
(\mathrm{kN})\end{array}$ & $\begin{array}{c}\text { Fc' } \\
(\mathrm{Kg})\end{array}$ & $\begin{array}{c}\text { Rata-rata } \\
(\mathrm{MPa})\end{array}$ \\
\hline 1 & AD.01 & $15 \times 30$ & 13,44 & 1 & 160 & 16315.46 & 9,05 & 10,87 \\
2 & AD.01 & $15 \times 30$ & 13,4 & 1 & 192 & 19578.55 & 8,81 \\
3 & AD.01 & $15 \times 30$ & 13,26 & 1 & 115 & 11726.73 & 6,51 \\
\hline \multicolumn{2}{l}{ Sumber: Hasil Uji } & & & & &
\end{tabular}

Tabel 6. Hasil Uji Kuat Tekan Beton Additive 0,1\% Umur 3 Hari.

\begin{tabular}{ccccccccc}
\hline No & $\begin{array}{c}\text { Kode Benda } \\
\text { Uji }\end{array}$ & Silinder & $\begin{array}{c}\text { Berat } \\
(\mathrm{Kg})\end{array}$ & $\begin{array}{c}\text { Umur } \\
(\text { hari })\end{array}$ & $\begin{array}{c}\text { Beban Maksimal } \\
(\mathrm{kN})\end{array}$ & $\begin{array}{c}\text { Fc' } \\
(\mathrm{Kg})\end{array}$ & $\begin{array}{c}\text { Rata-rata } \\
(\mathrm{MPa})\end{array}$ \\
\hline 1 & AD.01 & $15 \times 30$ & 13,08 & 3 & 393 & 40074.84 & 22,24 & 20,43 \\
2 & AD.01 & $15 \times 30$ & 13,14 & 3 & 361 & 36811.75 & 21,16 \\
3 & AD.01 & $15 \times 30$ & 13,23 & 3 & 368 & 37525.55 & 20,83 & \\
\hline \multicolumn{2}{l}{ Sumber: Hasil Uji } & & & & & &
\end{tabular}

Tabel 7. Hasil Uji Kuat Tekan Beton Additive 0,1\% Umur 7 Hari.

\begin{tabular}{ccccccccc}
\hline No & $\begin{array}{c}\text { Kode Benda } \\
\text { Uji }\end{array}$ & Silinder & $\begin{array}{c}\text { Berat } \\
(\mathrm{Kg})\end{array}$ & $\begin{array}{c}\text { Umur } \\
(\text { hari })\end{array}$ & $\begin{array}{c}\text { Beban Maksimal } \\
(\mathrm{kN})\end{array}$ & $\begin{array}{c}\text { Fc' } \\
(\mathrm{Kg})\end{array}$ & $\begin{array}{c}\text { Rata-rata } \\
(\mathrm{MPa})\end{array}$ \\
\hline 1 & AD.01 & $15 \times 30$ & 13,02 & 7 & 473 & 48232,6 & 26,77 & 25 \\
2 & AD.01 & $15 \times 30$ & 13,02 & 7 & 427 & 43541,9 & 24,17 & 24,06 \\
3 & AD.01 & $15 \times 30$ & 13,44 & 7 & 425 & 43337.93 & \\
\hline \multicolumn{5}{l}{ Sumber: Hasil Uji } & & & &
\end{tabular}

Tabel 8. Hasil Uji Kuat Tekan Beton Additive 0,2\% Umur 1 Hari.

\begin{tabular}{ccccccccc}
\hline No & $\begin{array}{c}\text { Kode Benda } \\
\text { Uji }\end{array}$ & Silinder & $\begin{array}{c}\text { Berat } \\
(\mathrm{Kg})\end{array}$ & $\begin{array}{c}\text { Umur } \\
(\text { hari })\end{array}$ & $\begin{array}{c}\text { Beban Maksimal } \\
(\mathrm{kN})\end{array}$ & $\begin{array}{c}\text { Fc' } \\
(\mathrm{Kg})\end{array}$ & $\begin{array}{c}\text { Rata-rata } \\
(\mathrm{MPa})\end{array}$ \\
\hline 1 & AD.02 & $15 \times 30$ & 12,96 & 1 & 189 & 19272.63 & 10,7 & 11,26 \\
2 & AD.02 & $15 \times 30$ & 12,94 & 1 & 199 & 20292.35 & 9,6 \\
3 & AD.02 & $15 \times 30$ & 12,86 & 1 & 121 & 12338.56 & 6,85 \\
\hline \multicolumn{2}{l}{ Sumber: Hasil Uji } & & & & & &
\end{tabular}

Tabel 9. Hasil Uji Kuat Tekan Beton Additive 0,2\% Umur 3 Hari.

\begin{tabular}{ccccccccc}
\hline No & $\begin{array}{c}\text { Kode Benda } \\
\text { Uji }\end{array}$ & Silinder & $\begin{array}{c}\text { Berat } \\
(\mathrm{Kg})\end{array}$ & $\begin{array}{c}\text { Umur } \\
(\text { hari })\end{array}$ & $\begin{array}{c}\text { Beban Maksimal } \\
(\mathrm{kN})\end{array}$ & $\begin{array}{c}\text { Fc' } \\
(\mathrm{Kg})\end{array}$ & $\begin{array}{c}\text { Rata-rata } \\
(\mathrm{MPa})\end{array}$ \\
\hline 1 & AD.02 & $15 \times 30$ & 13,26 & 3 & 342 & 34874.29 & 19,36 & 22,08 \\
2 & AD.02 & $15 \times 30$ & 13,8 & 3 & 390 & 39768.92 & 21,26 \\
3 & AD.02 & $15 \times 30$ & 13,8 & 3 & 395 & 40278.78 & 22,36 & \\
\hline \multicolumn{2}{l}{ Sumber: Hasil Uji } & & & & &
\end{tabular}


Tabel 10. Hasil Uji Kuat Tekan Beton Additive 0,2\% Umur 7 Hari.

\begin{tabular}{ccccccccc}
\hline No & $\begin{array}{c}\text { Kode Benda } \\
\text { Uji }\end{array}$ & Silinder & $\begin{array}{c}\text { Berat } \\
(\mathrm{Kg})\end{array}$ & $\begin{array}{c}\text { Umur } \\
(\text { hari })\end{array}$ & $\begin{array}{c}\text { Beban Maksimal } \\
(\mathrm{kN})\end{array}$ & $\begin{array}{c}\text { Fc' } \\
(\mathrm{Kg})\end{array}$ & $\begin{array}{c}\text { Rata-rata } \\
(\mathrm{MPa})\end{array}$ \\
\hline 1 & AD.02 & $15 \times 30$ & 13,06 & 7 & 383 & 39055.12 & 21,68 & 22,02 \\
2 & AD.02 & $15 \times 30$ & 13,12 & 7 & 389 & 39666.95 & 22,02 \\
3 & AD.02 & $15 \times 30$ & 13,08 & 7 & 440 & 44867.5 & 24,91 & \\
\hline \multicolumn{2}{l}{ Sumber: } & Hasil Uji & & & & & &
\end{tabular}

Tabel 11. Hasil Uji Kuat Tekan Beton Additive 0,3\% Umur 1 Hari.

\begin{tabular}{ccccccccc}
\hline No & $\begin{array}{c}\text { Kode Benda } \\
\text { Uji }\end{array}$ & Silinder & $\begin{array}{c}\text { Berat } \\
(\mathrm{Kg})\end{array}$ & $\begin{array}{c}\text { Umur } \\
(\text { hari })\end{array}$ & $\begin{array}{c}\text { Beban Maksimal } \\
(\mathrm{kN})\end{array}$ & $\begin{array}{c}\text { Fc' } \\
(\mathrm{Kg})\end{array}$ & $\begin{array}{c}\text { Rata-rata } \\
(\mathrm{MPa})\end{array}$ \\
\hline 1 & $\mathrm{AD} .03$ & $15 \times 30$ & 13,1 & 1 & 174 & 17743.06 & 9,8 & 12,81 \\
2 & AD.03 & $15 \times 30$ & 13,08 & 1 & 224 & 22841.64 & 11,27 \\
3 & AD.03 & $15 \times 30$ & 13,36 & 1 & 198 & 20190.38 & 11,2 \\
\hline Sumber: Hasil Uji & & & &
\end{tabular}

Tabel 12. Hasil Uji Kuat Tekan Beton Additive 0,3\% Umur 3 Hari.

\begin{tabular}{ccccccccc}
\hline No & $\begin{array}{c}\text { Kode Benda } \\
\text { Uji }\end{array}$ & Silinder & $\begin{array}{c}\text { Berat } \\
(\mathrm{Kg})\end{array}$ & $\begin{array}{c}\text { Umur } \\
(\text { hari })\end{array}$ & \multicolumn{2}{c}{$\begin{array}{c}\text { Beban Maksimal } \\
(\mathrm{kN})\end{array}$} & $\begin{array}{c}\text { Fc' } \\
(\mathrm{Kg})\end{array}$ & $\begin{array}{c}\text { Rata-rata } \\
(\mathrm{MPa})\end{array}$ \\
\hline 1 & $\mathrm{AD} .03$ & $15 \times 30$ & 13,06 & 3 & 447 & 45581.31 & 25,3 & 2,87 \\
2 & $\mathrm{AD} .03$ & $15 \times 30$ & 13,26 & 3 & 404 & 41196.53 & 22,37 \\
3 & AD.03 & $15 \times 30$ & 13,18 & 3 & 388 & 39564.98 & 21,96 & \\
\hline
\end{tabular}

Sumber: Hasil Uji

Tabel 13. Hasil Uji Kuat Tekan Beton Additive 0,3\% Umur 7 Hari.

\begin{tabular}{|c|c|c|c|c|c|c|c|c|}
\hline \multirow[t]{2}{*}{ No } & \multirow{2}{*}{$\begin{array}{c}\text { Kode } \\
\text { Benda } \\
\text { Uji }\end{array}$} & \multirow[t]{2}{*}{ Silinder } & \multirow{2}{*}{$\begin{array}{l}\text { Berat } \\
(\mathrm{Kg})\end{array}$} & \multirow{2}{*}{$\begin{array}{l}\text { Umur } \\
\text { (hari) }\end{array}$} & \multicolumn{2}{|c|}{ Beban Maksimal } & \multirow{2}{*}{$\begin{array}{c}\mathrm{Fc}^{\prime} \\
(\mathrm{MPa})\end{array}$} & \multirow{2}{*}{$\begin{array}{c}\text { Rata-rata } \\
\text { (MPa) }\end{array}$} \\
\hline & & & & & $(\mathrm{kN})$ & $(\mathrm{Kg})$ & & \\
\hline 1 & AD.03 & $15 \times 30$ & 13,04 & 7 & 529 & 53942.98 & 29,94 & \\
\hline 2 & AD.03 & $15 \times 30$ & 13,26 & 7 & 517 & 52719.32 & 29,27 & 29,09 \\
\hline 3 & AD.03 & $15 \times 30$ & 13 & 7 & 496 & 50577.91 & 28,08 & \\
\hline
\end{tabular}

Sumber: Hasil Uji

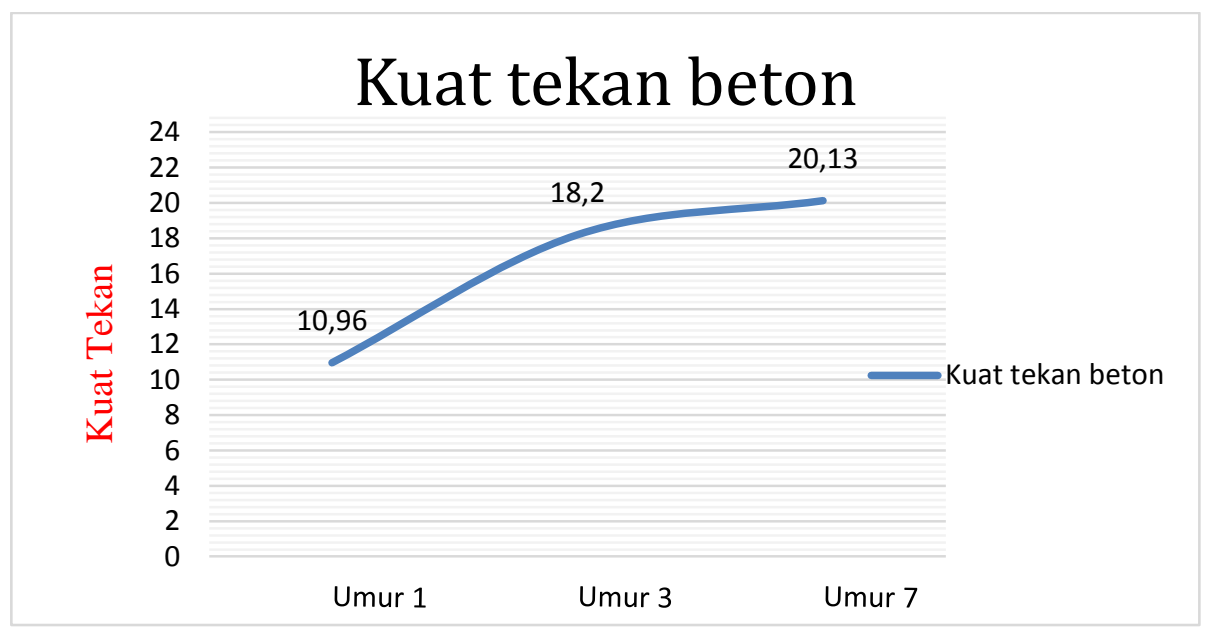

Gambar 4. Grafik Kuat Tekan Beton Normal Sumber: Hasil Uji 


\section{Kuat tekan beton}

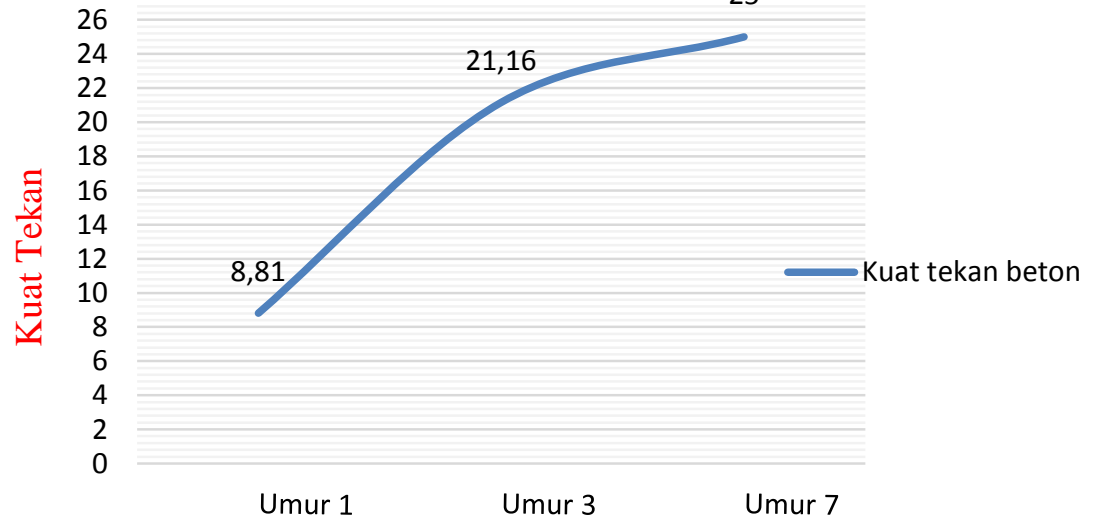

Gambar 5. Grafik Kuat Tekan Beton Additive 0,1\% Sumber: Hasil Uji

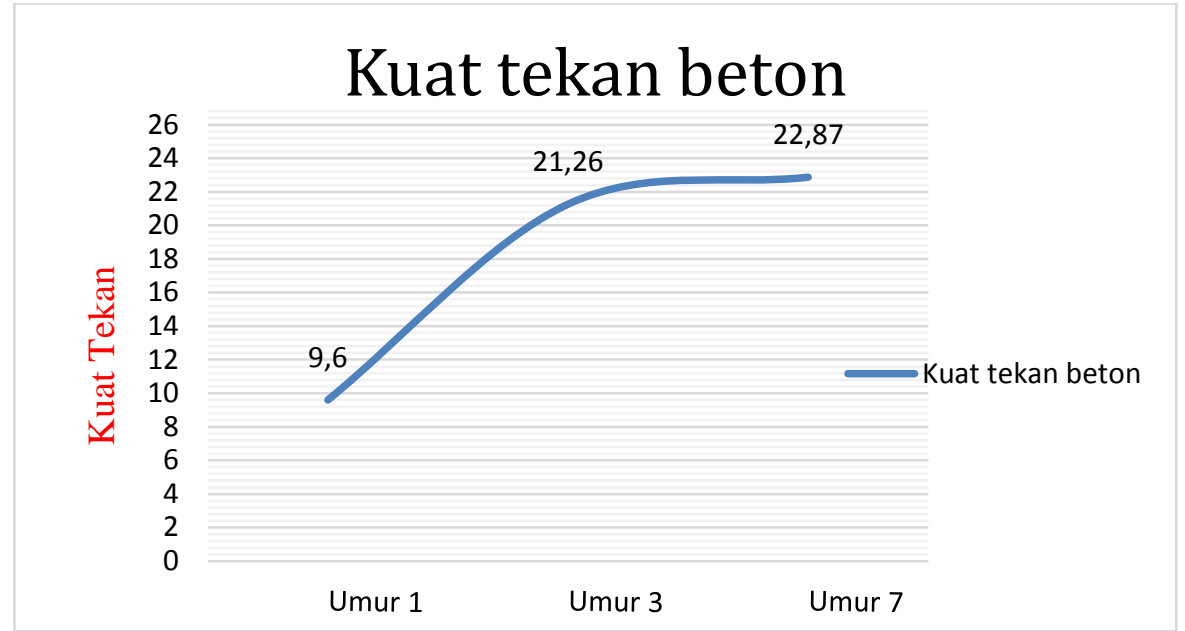

Gambar 6. Grafik Kuat Tekan Beton Additive 0,2\% Sumber: Hasil Uji

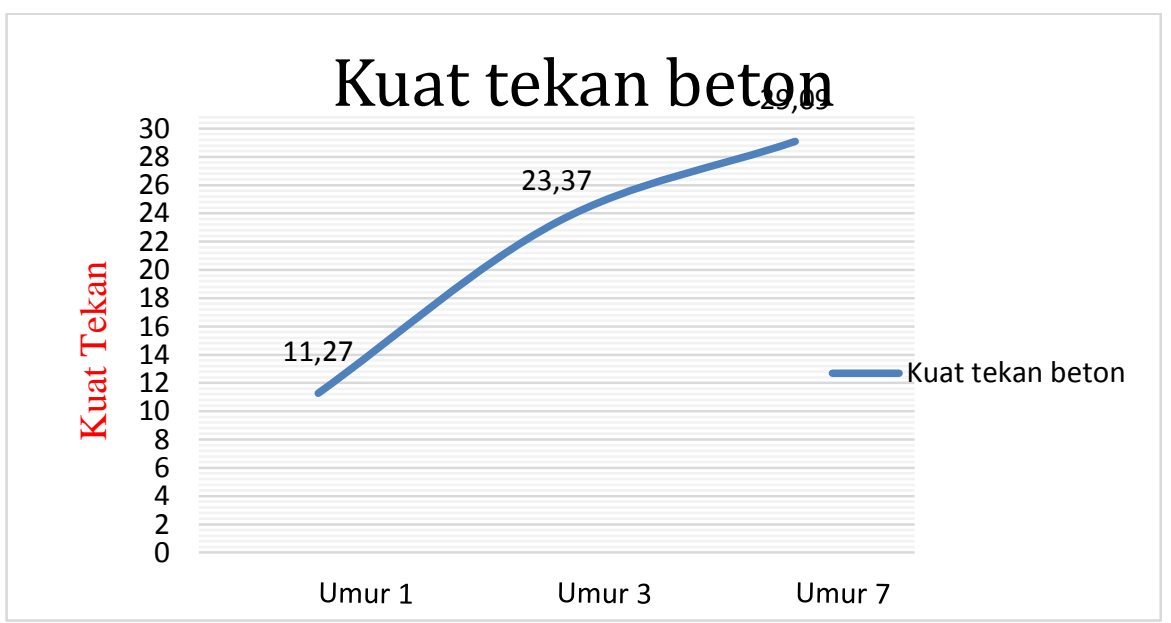

Gambar 7. Grafik Kuat Tekan Beton Additive 0,3\% Sumber: Hasil Uji 
Dari tabel 2. - 13. dan gambar 4. - 7. di atas dapat dilihat bahwa kuat tekan beton yang tertinggi terdapat pada campuran zat additive Master Glenium Ace 8111 0,3\% (AD.03) yaitu sebesar 29,09 MPa pada umur 7 hari, 23,37 $\mathrm{MPa}$ pada umur 3 hari, 11,27 $\mathrm{MPa}$ pada umur 1 hari dan kuat tekan beton yang terendah terdapat campuran zat additive 0\% (Normal) yaitu sebesar 20,13 MPa pada umur 7 hari, 18,2 MPa pada umur 3 hari, 10,96 MPa pada umur 1 hari. Dari data di atas dapat dilihat bahwa dengan penambahan zat additive Master Glenium Ace 8111 mempunyai kuat tekan lebih tinggi dibandingkan dengan beton variasi campuran zat additive lainnya. Pengaruh zat additive Master Glenium Ace 8111 menaikan nilai kuat tekan beton, selain menaikan kuat tekan beton, zat additive Master Glenium Ace 8111 dapat memudahkan saat pengerjaan pembuatan beton tanpa mengurangi nilai kuat tekan mutu beton ini. Pada benda uji campuran zat additive Master Glenium Ace $81110 \%$ (Normal) terdapat beberapa masalah diantaranya:

i. Pada saat pengadukan beton sangat sulit untuk diaduk karena kadar airnya sedikit sehingga susah saat proses pembuatan beton

ii. Pada saat cetakan silinder dibuka banyak sampel silinder yang permukaan atasnya tidak rata, sehingga pada saat pengujian kuat desak beton tidak sesuai dengan yang diharapkan. Adukan dengan tingkat kelecakan tinggi mempunyai resiko yang besar terhadap terjadinya bleeding, hal ini terjadi pada semua sampel beton.

Dari penelitian terlihat bahwa penggunaan zat additive Master Glenium Ace 8111 bisa dijadikan sebagai alternatif. Hal ini terlihat dari tabel dan gambar diatas bahwa kenaikan kuat tekan terjadi pada setiap dosis campuran zat additive Master Glenium Ace 8111.

\section{KESIMPULAN}

Berdasarkan penelitian "Analisis Kuat Tekan Beton Fast Track dengan Bahan Tambah Master Glenium Ace 8111 " yang telah dilakukan dapat diambil kesimpulan bahwa:

1. Kuat tekan beton normal pada umur 1 hari dengan semua varian dosis zat additive Master Glenium ACE 8111 maupun tanpa zat additive Master Glenium ACE 8111 sebesar 10,96 MPa untuk campuran zat additive $0 \%, 8,81 \mathrm{MPa}$ varian dosis zat additive $0.1 \%, 9,60 \mathrm{MPa}$ varian dosis zat additive 0.2\%, 11,27 MPa varian dosis zat additive $0.3 \%$.

Kuat tekan beton normal pada umur 3 hari dengan semua varian dosis zat additive Master Glenium ACE 8111 maupun tanpa zat additive Master Glenium ACE 8111 sebesar 18,20 MPa untuk campuran zat additive 0\%, 21,16 MPa varian dosis zat additive $0.1 \%, 21,26 \mathrm{MPa}$ varian dosis zat additive $0.2 \%, 23,37$ $\mathrm{MPa}$ varian dosis zat additive $0.3 \%$.

Kuat tekan beton normal pada umur 7 hari dengan semua varian dosis zat additive Master Glenium ACE 8111 maupun tanpa zat additive Master Glenium ACE 8111 sebesar 20,13 MPa untuk campuran zat additive 0\%, $25 \mathrm{MPa}$ varian dosis zat additive $0.1 \%, 22,87 \mathrm{MPa}$ varian dosis zat additive 0.2\%, 29,09 $\mathrm{MPa}$ varian dosis zat additive $0.3 \%$.

2. Dari data yang didapat beton dengan campuran zat aditive Master Glenium ACE 8111 dengan dosis 0,3\% memiliki kuat tekan maksimum.

\section{DAFTAR PUSTAKA}

[1] Fitria dan Asna, 2003, TINJAUAN PEMAKAIAN SUPERPLASTICIZER PADA BETON MUTU TINGGI TERHADAP KUAT DESAK DAN KADAR OPTIMUM, Tugas Akhir Jenjang S-1 FTSP UII, Yogyakarta.

[2] Murdock, L. J., dan Brook, K. M., 1986, BAHAN DAN PRAKTEK BETON, Terjemahan, Erlangga, Jakarta.

[3] Murdock, L. J., dan Brook, K. M., 1991, BAHAN DAN PRAKTEK BETON, Erlangga, Jakarta.

[4] McCormac, dan Jack C, 2004, DESAIN BETON BERTULANG, Terjemahan, Erlangga, Jakarta.

[5] Ghozali, Risdhika, dan Anggita. 2010, PENGARUH PENGGUNAAN PECAHAN KERAMIK SEBAGAI BAHAN PENGGANTI AGREGAT KASAR.

[6] Tjokrodimuljo, K., 1992, Bahan Bangunan, Jurusan Teknik Sipil, Fakultas Teknik Universitas Gadjah Mada, Yogyakarta.

[7] Tjokrodimuljo, K., 1996, Teknologi Beton, Jurusan Teknik Sipil, Fakultas Teknik Universitas Gadjah Mada, Yogyakarta.

[8] Antoni, dan Paul Nugraha., 2007, TEKNOLOGI BETON. Penerbit C.V Andi Offset, Yogyakarta. 
